\title{
Doctoring Beauty: The Medical Control of Women's Toilettes in France, 1750-1820
}

\author{
MORAG MARTIN*
}

On 4 September 1818 the Gazette de France reported on the tumultuous scenes occurring outside Parisian booksellers. The journalist was surprised to find crowds of people all demanding one book:

I noticed many women in their carriages, who waited impatiently for the return of their husbands ... they had their eyes fixed on the store, their necks craned, their arms outstretched; they grabbed rather than received the book, they devoured it rather than perused it ...

The sought-after tome was the Alliance d'hygie [sic] et de la beauté, newly arrived in stores. The Alliance was a history of beauty and a complete guide for female behaviour written by Dr J B Mège, a member of the medical faculty of Paris. The scenes of chaos that it caused indicate the huge popularity in the early nineteenth century of works that proposed to divulge beauty secrets. This popularity had its roots in the eighteenth century, when the genre of beauty manuals provided an alternative to calls for a ban on all cosmetics found in tracts, novels and newspapers. Educated women of the middle and upper classes found solace in the pages of advice manuals. ${ }^{2}$ This genre not only provided women with recipes, but set the boundaries for the practices of beautification. Increasingly it was the practitioners of medical science who dictated these boundaries.

Eighteenth-century female aristocrats traditionally wore thick layers of white paint and large streaks of rouge across their faces, from the corner of the mouth to the tip of the ear. Beauty patches, sometimes as big as golf balls or shaped like birds, completed the face, and towering powdered hairpieces topped off the look. Though their fashions differed in shape, men adorned themselves with many of the same toiletries. The growth of demand for populuxe goods in the mid-century, allowed the middle and artisan classes to participate in

(C) Morag Martin 2005

* Morag Martin, PhD, Assistant Professor of History at SUNY Brockport, Brockport, NY 14420, USA.

I would like to thank Colin Jones and Timothy Tackett for their support with this work. I would also like to thank Margaret Pelling and her Medicine and Culture Seminar for letting me give a version of this paper at Oxford University, 10 June 2002.

\footnotetext{
1 “Je remarquai plusieurs dames, qui dans leurs voitures, me semblaient attendre avec humeur le retour de leur mari ... elles avaient l'oeil fixé sur le magasin, le col tendu, le bras hors de la portière; elles arrachaient plutôt qu'elle ne recevaient le livre, elles le devoraient plutôt qu'elles ne le parcouraient", Affiches Parisiennes ou Gazette de France, 4 Sept. 1818, 247: pp. 1033-35, on p. 1033 ; Jean-Baptiste Mège,
}

Alliance d'hygie et de la beauté, ou l'art d'embellir, d'après les principes de la physiologie; précédé d'un discours sur les caractères physiques et moraux de la femme, ses prérogatives et ses devoirs, et sur les moeurs et les coutumes des Anciens, Paris, Eberhart, 1818.

${ }^{2}$ In the late eighteenth century, 62 per cent of Parisian female wage-earners and 92 per cent of female servants could sign their names. Almost 100 per cent of middle- and upper-class women could do so, indicating that the number of literate women in Paris was high enough to justify the creation of genres aimed solely at them. Daniel Roche, The people of Paris: an essay in popular culture in the 18th century, trans. Marie Evans, Berkeley, University of California Press, 1987, pp. 158, 199-203. See also Robert Muchembled, Société, cultures, et mentalités dans la France moderne, Paris, Armand Colin, 1994, pp. 140-1. 


\section{Morag Martin}

the practices of the wealthy, especially when it came to fairly affordable products such as make-up. Artisans and servants could buy white face paint and rouge cheaply in the stores of perfumers or on street corners from itinerant sellers. The third estate wore its make-up differently than the aristocracy, preferring tones of pink to red, and circular patterns to streaks. None the less, by the late eighteenth century all but the very poor participated in the pleasures of make-up. ${ }^{3}$

As cosmetics became more visible in shops and on toilette tables, ${ }^{4}$ so did their critics. Attacks against cosmetics were not new, going back to their introduction into French high society in the sixteenth century. Religious arguments against wearing make-up were common in the late seventeenth and early eighteenth century. ${ }^{5}$ Increasingly, however, secular critics became prominent, arguing for a complete rejection of all forms of artifice by men and women alike. Men were the first to be lambasted for their proclivity for makeup. Critics specifically argued that men were feminized and weakened through their participation in beautification. Though élite men continued to wear wigs and powder well into the revolutionary years, by the 1780 s most had given up the rouge and paint that had previously ornamented the face. ${ }^{6}$ Cosmetics were still under attack, but now they were primarily a feminine concern, and thus had to be discredited as unfit for a new simpler version of femininity.

Enlightened philosophes were among some of the most virulent critics. Driven by a desire to create a self-evident hierarchy of merit, they criticized cosmetics for sustaining aristocratic debauchery and fashions that promoted deceit by women of all social groups. Not only were individual women no longer distinguishable by rank, but their new faces were false and ugly. What was needed was a purification of the masked face, to reveal the true transparent personality underneath, which could then be judged by reason rather than birth. The science of physiognomy, the reading of facial traits, provided a basis on which calls for a return to natural beauty rested. Cosmetics were vile masks that could hide a corrupt physiognomy, incapable of reproducing the true beauty of the pure soul. ${ }^{7}$

Moral and aesthetic arguments against cosmetics, though they were based on a popular scientific system and championed by the philosophes, had little real authority when it came to changing women's habits. As long as cosmetics remained socially acceptable, the claim that they were unattractive and immoral had little weight in the salons of fashionable ladies.

\footnotetext{
${ }^{3}$ The spread of use can be found in commentaries by contemporaries, in the account books of perfumers and in the significant drop in prices of these goods found in advertisements. For an analysis of these sources, see Morag Martin, 'Consuming beauty: the commerce of cosmetics in France 1750-1800', $\mathrm{PhD}$ thesis, University of California, Irvine, 1999, ch. 2 The term populuxe was first coined by Cissie Fairchild to mean cheap imitations of luxury goods. Cissie Fairchild, 'The production and marketing of populuxe goods in eighteenth-century Paris,' in John Brewer and Roy Porter (eds.), Consumption and the world of goods, London, Routledge, 1993, p. 228.

${ }^{4}$ The term "toilette" in the eighteenth century referred both to the space, the "cabinet de toilette", and
}

to the daily act of beautification that took place there. I will be using it to mean the practice of beautification, and for clarity will use "cabinet de toilette" or toilette table when I am referring to the space.

${ }^{5}$ Marcel Braunschvig, La femme et la beauté, Paris, Armand Collin, 1929, p. 80.

${ }^{6}$ Once wigs were given up, the main masculine cosmetic purchases in the early nineteenth century were hair products, specifically for stimulating hair or dyeing it. Morag Martin, 'The great masculine renunciation: coping with male hair loss 1770-1830', unpublished manuscript.

${ }^{7}$ Martin, op. cit., note 3 above, ch. 3; Morag Martin, 'Casanova and Mlle Clairon: painting the face in a world of natural fashion,' Fashion Theory, 2003, 7: pp. 57-78. 
Clearly, a more persuasive argument was needed, one that could appeal to Enlightenment philosophes, conservative moralists and the women who still wore rouge and paint. This argument was found in the realm of science: medical opinions against the use of cosmetics could be empirically proved and might be more capable of inspiring fear and awe in fashion-conscious females. If cosmetics could be shown to cause the appearance of wrinkles and, even more disastrously, an early death, then women might be persuaded to reform their ways. Soon, doctors, perfumers and critics of cosmetics made medical arguments against their use central to harangues aimed at women.

The growing medical authority over women's fashions was part of a larger shift towards creating healthier subjects through science. Michel Foucault argued that medical practitioners gained power in the late eighteenth century as a result of the political importance of hygiene and health for social control. Doctors infiltrated élite family units as advisers and controllers of personal habits. ${ }^{8}$ The new bourgeois body was to be created through practices of hygiene and healthful behaviour, instituted by science and policed by the self. Philippe Perrot believes that doctors' advice in the name of "rationality and a well assured technical prowess ... acquired a legitimacy and a new pertinence" in the context of a hygienic revolution. ${ }^{9}$ This legitimacy helped doctors create a professional ethos with which to attack charlatans, faith healers and midwives. At the centre of this struggle was the metaphorical and physical control of women's bodies.

As Foucault himself stated, power is a productive as well as a repressive force. ${ }^{10}$ The medicalization of the female body was not a one-sided story of oppression by the masculine gaze. Women were not the passive pawns of a contest for professional legitimacy, but actively involved in shaping the definition of medical bodies. Lindsay Wilson shows that the medical control of women's bodies was inconclusive and tenuous in the late eighteenth century. The medical practitioner's authority was constantly under attack due to a lack of medical progress in the realm of feminine diseases. ${ }^{11}$ Women's voices and gazes continued to play a part in the creation of knowledge, helping to discredit certain theories while giving credence to others. Male doctors may have carved a specific niche for themselves, but it was one that necessitated compromise rather than guaranteed tyrannical control.

Central to this struggle for medical supervision in cooperation with women of the élite was the promotion of hygienic habits that were meant to replace the artificial and complex

\footnotetext{
${ }^{8}$ Michel Foucault, 'The politics of health in the eighteenth-century,' in Paul Rabinow (ed.), The Foucault reader, London, Penguin, 1984, pp. 273-90, on pp. 279-84. The late eighteenth-century "birth of the clinic" reinforced this medical control, further objectifying the body under the clinical gaze, which judged and punished patients for their pathologies. Michel Foucault, Birth of the clinic: an archaeology of medical perception, trans. A M Sheridan, London, Tavistock Publications, 1973; Barbara Duden, The woman beneath the skin: a doctor's patients in eighteenth-century Germany, trans. Thomas Dunlap, Cambridge, Harvard University Press, 1991, pp. 3-4, 14-15.

9 “... rationalisme et d'un pouvoir technique mieux assuré ... acquiert une légitimité et une pertinence
}

nouvelles", Philippe Perrot, Le travail des apparences, ou les transformations du corps féminin XVIIIe-XIXe siècle, Paris, Éditions du Seuil, 1984, p. 75.

${ }^{10}$ Michel Foucault, 'Truth and power', in Colin Gordon (ed.), Power/knowledge: selected interviews and other writings, 1972-1977, New York, Pantheon Books, 1980, p. 119.

${ }^{11}$ Lindsay Wilson, Women and medicine in the French Enlightenment: the debate over 'maladies des femmes', Baltimore, Johns Hopkins University Press, 1993, pp. 5-6. See also Ludmilla Jordanova, Sexual visions: images of gender in science and medicine between the eighteenth and twentieth centuries, Madison, University of Wisconsin Press, 1989. 


\section{Morag Martin}

grooming of the aristocracy. Georges Vigarello has convincingly showed that by the end of the century hygiene had become the new, fashionable means of achieving both health and beauty. Up until then, physicians feared that water would enter the body through the pores and contaminate the internal organs, affecting the humoral balance. Increasingly, medical practitioners tried to encourage their readers to bathe more frequently and use water instead of oils to wash their faces and bodies. Public baths opened on the Seine in 1761, heartily supported by new medical findings. Though private bathtubs remained infrequent, by the end of the century basins were not an uncommon sight in the cabinets de toilette of the middle and upper classes. These were used to combat disease, grime and repair the ravages caused by make-up. ${ }^{12}$ The well-known physician S A D Tissot recommended "water as the only valuable cosmetic". ${ }^{13}$ Louis-Sébastien Mercier concurred, proclaiming that the only real adornment for a woman was "cleanliness, cleanliness, cleanliness". ${ }^{14}$ If bathing was now encouraged, the use of strong scents to mask bodily smells was strongly discouraged. Alain Corbin argues that the hygienic revolution was matched by a transformation in scents, shifting from animal perfumes to lighter vegetable scents. The fashion for fresh smells emphasized the natural over the artificial as both more attractive and more beneficial for health. ${ }^{15}$

The growing concern with health and hygiene led doctors to advise women to keep both their faces and their bodies clean and pure through a series of private acts. The use of light scents, washing with water and soap, exercise and less-constraining clothing were all promoted as private practices that could help strengthen the body and stave off illness. ${ }^{16}$ This emphasis on bodily health distinguished between the new bourgeois or enlightened family and the aristocratic model. Wilson asserts that women were the primary targets or clients for enlightened medicine because of their increasingly central position within the household economy. The patronage of upper- and middle-class women could lead to lucrative medical contracts. ${ }^{17}$ Doctors were specifically needed to instruct women in preventative medicine for themselves and their families, and the realm of hygiene and fashion was an important first step in this process. If medical men could gain women's trust in their private ministrations, then their general advice would be more likely to be followed in the home. ${ }^{18}$

Within the wider sphere of private grooming, cosmetics were central to the redefinition of a healthy toilette. By focusing on the use of make-up and other cosmetics, doctors tapped into a productive and profitable position as beauty advisers, one that would allow them entry into women's private lives. By the end of the eighteenth century, the physician became the main purveyor of beauty advice, overshadowing the professional perfumer, the

\footnotetext{
${ }^{12}$ Georges Vigarello, Le propre et le sale: l' hygiène du corps depuis le Moyen Age, Paris, Éditions du Seuil, 1985, pp. 107-110, 116, 173, 127-128.

13 “... l'eau comme seul cosmétique valable”, S A D Tissot, Essai sur les maladies des gens du monde, Paris, 1771, p. 108.

14 “.... propreté, propreté, propreté”,

Louis-Sébastien Mercier, Tableau de Paris, 13 vols, Paris, 1783, vol. 11, p. 72.

${ }^{15}$ Alain Corbin, The foul and the fragrant: odor and the French social imagination,
}

Cambridge, MA, Harvard University Press, 1986, pp. 71-85.

${ }^{16}$ Perrot, op. cit., note 9 above, p. 78; Daniel Roche, La culture des apparences, Paris, Fayard, 1989, pp. 441-3. On the history of exercise, see Chloe Underwood, 'Exercising virtue: the physical reform of the leisured elite in eighteenth-century

France', $\mathrm{PhD}$ thesis, University of Warwick, 2000.

${ }^{17}$ Wilson, op. cit., note 11 above, p. 95.

${ }^{18} \mathrm{D}$ J Fargeon, L'art du parfumeur, Paris, Delalain fils, 1801, p. 184. 
hairdresser or the apothecary. ${ }^{19}$ Physicians had the professional knowledge necessary to counsel female users, without the fear of commercial self-interest. Stressing scientific rationality and truth, they disassociated cosmetics from aristocratic decadence and immoral coquettes. Instead, physicians created a vision of healthy and hygienic beauty that placed female vanity within the domestic sphere, always under the strict eye of a trained professional. Stressing safety, doctors could influence women in their choice of products.

The increased visibility of doctors in the practices of beautification (through advice literature or counselling) was a direct response to the growing concern over the potentially life-threatening ingredients included in the recipes for many cosmetics. The use of arsenic, lead, potash and other chemicals in rouge and face-paint alarmed doctors and the public. By the end of the eighteenth century a growing number of diseases and even deaths were blamed on artifice, increasing the public's concern for regulating both home and commercial production of noxious goods. ${ }^{20}$ Using medical experimentation, doctors asserted that the ingredients commonly used in cosmetics would damage not only the skin but also the overall health of the wearer. A plethora of scientific knowledge was marshalled to prove that the ingredients in cosmetics were lethal to the health of the French public.

Yet, by choosing to give women advice and judging cosmetic products empirically, doctors placed themselves at the centre of the growing debate on fashion and artifice. They could not limit themselves to scientific observations if they wished to counsel those most likely to be harmed by poisons. They had to appeal to their audience of female readers. So, instead of adopting prescriptive and threatening tones, these medical men operated within the boundaries of the genre they worked in. The advice manual by definition provided readers with practical solutions to problems. To gain popularity and readership, physicians' manuals had to advocate some use of beauty aids and provide replacements for those goods they defined as dangerous. The physicians of France, thus, distinguished between goods deemed noxious and those that fitted models of hygiene, health and, most importantly, safety as judged by science. Medical doctors entered the cabinets de toilette of their female patients and readers in the spirit of cooperation. Though they were now central to the debate about the use of cosmetics, their willingness to tolerate medically safe products put them at odds with the overwhelming criticism of all things artificial. By relying on their self-imposed methods of examination and adopting the genre of advice manuals to publicize their findings, medical professionals unwittingly authenticated and perpetuated cosmetic consumption in the name of science for the women of France.

\footnotetext{
${ }^{19}$ Of the nineteen beauty advice manuals aimed at women published between 1750 and 1818, when Mège's work appeared, half were by doctors, with the others by perfumers, apothecaries, chemists, dentists or more general commentators. Most advice literature not written by doctors referred to medical opinion or copied large sections from the works of doctors. For instance, the perfumer D J Fargeon in
}

his L'art du parfumeur (1801) copied and updated Antoine Le Camus' Abdeker, ou l'art de conserver la beauté (1754). Increasingly chemists and perfumers published books aimed solely at their professional colleagues.

$20 \mathrm{~J}$ A Chaptal, Elémens de chymie, 3 vols, Paris, 1796, vol. 2, pp. 278-9; Maggie Angeloglou, A history of make-up, London, Macmillan, 1970, p. 75. 


\section{Morag Martin}

\section{Deadly Artifice: Medical Science Judges Cosmetics}

Scientific opinion had condemned the use of chemical ingredients, such as camphor and lead, in beauty aids since the sixteenth century. Yet, most doctors who wrote on cosmetics prior to the eighteenth century did so to promote their own recipes, rather than to critique fashions using their medical knowledge. ${ }^{21}$ For example, one of the médecins $d u$ roi published a recipe book on cosmetics in 1661, following the tradition of the notorious doctor Michel de Nostredame in the $1550 \mathrm{~s} .{ }^{22}$ These works and those that came after offered a variety of well-known recipes and said little about the actual dangers of make-up. In many treatises on health published during the seventeenth century, cosmetics were considered medicines for the face and skin. ${ }^{23}$ The late seventeenth and early eighteenth centuries did see the rise of medical manuals meant to correct the mistakes of earlier books of secrets. Doctors focused on teaching patients how to keep clean, prevent illness and avoid the "dangers of quacks and popular errors". ${ }^{24}$ One of the main thrusts of these works was to promote forms of hygiene that would further health, but none directly addressed the problem of cosmetics.

It was not until the mid-eighteenth century that doctors started to write serious tomes on beauty and cosmetic use. Physicians began using chemical and medical knowledge to comment on the effects of paint. Empiricism became the main criterion for determining the worth of ingredients and products. ${ }^{25}$ Chemists, doctors and scientists tested and analysed the qualities of each ingredient, not on actual subjects, but in laboratory experiments. Minerals such as lead, mercury and sulphur were singled out as damaging to the skin due to their chemical properties. Though there was no strict agreement amongst scientists as to the extent of the possible harm, all doctors agreed that these were noxious ingredients not suited for beauty products. These warnings escalated as new discoveries were made in science. The updated 1756 version of the seventeenth-century Cours de chymie still encouraged the inclusion of bismuth and lead in skin whiteners. ${ }^{26}$ In 1804 , the physician P J Marie de Saint-Ursin in his L'ami des femmes cautioned that these same chemicals induced skin eruptions and would eventually lead to grave maladies. ${ }^{27}$ Ingredients that were truly hazardous and might actually be deadly became increasingly identified as such by the medical community.

\footnotetext{
${ }^{21}$ Evelyn Berriot-Salvadore, Un corps, un destin, la femme dans la médecine de la Renaissance, Paris, Honoré Champion, 1993, p. 95.

${ }^{22}$ Michel de Nostredame, Excellent et très utile opuscule à tous nécessaire, de plusieurs exquises recettes ...fard, Lyon, A Volant, 1555; Lazare Meyssonnier, Recueil de secrets pour la conservation de la beauté, Paris, 1661.

${ }^{23}$ See Jean de Renou, Oeuvres pharmaceutiques, Lyon, chez Antoine Chard, 1626, p. 80.

${ }^{24}$ Matthew Ramsey, 'The popularization of medicine in France 1650-1900', in Roy Porter (ed.), The popularization of medicine, 1650-1850, London, Routledge, 1992, pp. 97-133, on pp. 107, 113.
}

\footnotetext{
${ }^{25}$ Laurence Brockliss and Colin Jones, The medical world of early modern France, Oxford, Clarendon Press, 1997, p. 668. Empiricism and observation also became the main means of determining the efficacy of a medicine. Doctors of the late eighteenth-century gave up on the traditional explanations, often based on humoral theories, of why and how drugs worked and instead tried to determine their effects on patients. Ibid., p. 437.

${ }^{26}$ Nicolas Lémery, Cours de chymie, 1677 , reprinted Paris, 1756, pp. 115-16.

${ }^{27}$ P J Marie de Saint-Ursin, L'ami des femmes, ou, Lettres d'un médecin, Paris, chez Barba, 1804, pp. 288-9.
} 
When doctors analysed a cosmetic they were most concerned with the use of "mineral, metallic or saline" ingredients rather than vegetable and animal ones. ${ }^{28}$ Marie de SaintUrsin listed nitric acid and mercury as unwholesome additions, unlike cucumbers, almond paste, milk, honey and egg yolks. ${ }^{29}$ Recipes for rouge that were made with plants such as red sandalwood or saffron were acceptable, whereas minium (lead oxide) and cinnabar (red mercury sulphur) were to be avoided. ${ }^{30}$ Remedies containing strawberry juice, melon seeds, hazelnuts and distilled beef bile were postulated as replacements for cosmetics made out of lead and other minerals. ${ }^{31}$ This dichotomy led to a distinction between "harmful" mineral ingredients and "natural" vegetable and animal ones, often harking back to a past tradition of purer recipes. Playing on images of natural beauty, doctors categorized mineral elements as less pure than vegetable matter. ${ }^{32}$

Primarily concerned with the dangers of minerals, doctors focused their attention first on the corruption of the outer layers of the skin. The imagery in medical texts was of rotting, diseased flesh. This corruption of the flesh was the ironic outcome of products intended to mask already present flaws. Creams made with lead or bismuth promised to "whiten the skin, soften wrinkles", but the chemical properties of these concoctions meant that their effects presented "a much more disagreeable picture than the natural blemishes which women were so obsessed with correcting". ${ }^{33}$ One physician felt that all skin creams and paint plugged the skin's pores, impeding natural sweat, causing dryness as well as "skin diseases, pimples, scabs, redness". ${ }^{34}$ Rouge was also under attack, as it too could cause itching, acne and eruptions, unseemly blemishes to youthful skin. ${ }^{35}$

Cosmetics also threatened the integrity of the mouth. Medical men terrified readers with pictures of rotting, crumbling teeth attacked inside and out by vile products. The doctor Antoine Le Camus warned women that the mercury in rouge would cause them to "lose their teeth, acquire bad breath, or to have abundant discharges of saliva". ${ }^{36}$ Healthy teeth were essential to the face's overall beauty. ${ }^{37}$ The mouth was a symbol of potency and sexuality in the eighteenth century. The frequency of bad teeth and stinking breath led to

\footnotetext{
28 “... minéral terreuse, métallique ou saline ...”, Mercure de France, March 1773, pp. 193-4. p. 301 .

${ }^{29}$ Marie de Saint-Ursin, op. cit., note 27 above,

${ }^{30}$ Pierre-Joseph Buc'hoz, Toilette de Flore, Paris, 1771, p. 198; Abbé Jaubert, Dictionnaire raisonné universel des arts et métiers, 4 vols, Paris, chez P Fr Didot jeune, 1773, vol. 3, pp. 362-3.

${ }^{31}$ Jaubert, op. cit., note 30 above, vol. 4, p. 270.

${ }^{32}$ In the treatment of venereal diseases, a similar shift was made to vegetable cures. Advertisements for these claimed that mercury had been replaced by vegetable ingredients. Brockliss and Jones, op. cit., note 25 above, pp. 633-6, 776.

33 “... blanchir la peau, d'adoucir les rides", "un tableau bien plus désagréable, que les défauts naturels auxquels les femmes sont si jalouses de remédier", Philippe Macquer, Dictionnaire portatif des arts et métiers, contenant
}

en abrégé l' histoire, la description et la police des arts et métiers, 2 vols, Paris, chez Lacombe, 1766, vol. 2, p. 349 .

34 "... . des maladies de peau au visage, des boutons, des dartres, des rougeurs", Achille-Guillaume Le Bègue de Presle, Le conservateur de la santé, ou avis sur les dangers qu'il importe à chacun d'éviter, Paris, chez P Fr Didot le jeune, 1763 , p. 350 .

${ }^{35}$ Deshais Gendron, Lettre à Monsieur*** sur plusieurs maladies des yeux causées par l'usage du rouge et du blanc, Paris, 1760, p. 24.

36 "... perdre leurs dents, acquérir une mauvaise haleine, ou avoir un flux de salive trop abundant", Antoine Le Camus, Abdeker, ou l'art de conserver la beauté, 2 vols, Paris, 1754, vol. 1, pp. 203-4.

${ }^{37}$ Bernard Bourdet, Soins faciles pour la propreté de la bouche, pour la conservation des dents et pour faire éviter aux enfans les accidents de la dentition, Paris, J-T Hérissant père, 1771, p. 11. 


\section{Morag Martin}

a culture in which the smile was a rare practice in polite company. ${ }^{38}$ Cosmetics were all the more insidious if they undermined the wearer's smile, leading to the desperate use of false teeth. Attempts to fix the ravages of cosmetics with other chemical products led to further destruction. Doctors warned that opiates or teeth whiteners would strip the teeth of their enamel. The promises of dentists were also not to be trusted. Naïve clients would find themselves with even less to laugh about. ${ }^{39}$

The loss of beauty was not the only consequence of adopting artifice. Disease and death were the inevitable rejoinders to fading looks. Once the skin was exposed and damaged, the chemicals in cosmetics affected the functioning of the senses and even the internal organs. Eighteenth-century humoral theory postulated that any foreign element in contact with the body forced normally expelled fluids into key organs or blood vessels, destabilizing the body's balance. Thickly applied cosmetics blocked transpiration. ${ }^{40}$ Creams adopted to remove stains and acne had the ability to "transfer dangerous materials to internal organs". ${ }^{41}$ Certain cosmetics were singled out as especially hazardous. In 1760, the physician Deshais Gendron believed that the high rate of pulmonary disease among rich women was brought on by the white paint they applied on their face, neck and chest, which attacked "the porous substances of the lungs". ${ }^{42}$ Gendron, using highly scientific terminology, laid out precise, convincing reasons for the rejection of face paint, hoping to scare his readers away from the practices of artifice.

Medical science not only pinpointed the dangers of cosmetic use but also alleviated one of the main reasons for adopting them. Many women justified the wearing of paint as a means to cover the scars of disease, especially smallpox. The threat of scars was so strong that in Dangerous acquaintances, P A F Choderlos de Laclos chose to punish Madame de Merteuil for her immoral behaviour by having her horrendously disfigured by the disease. ${ }^{43}$ Patients were warned that "if you dare scratch yourself, you will become so hideous that no one will love you thereafter"; an injunction that was said to be most effective. ${ }^{44}$ By the late eighteenth century, however, incidents of smallpox declined due to popularization

\footnotetext{
${ }^{38}$ The prevalence of quacks selling opiates (toothpowders), false teeth or miracle cures for tooth whitening indicates the desperate measures many were willing to take. Colin Jones is currently writing a book on dentistry in eighteenth-century France. See Colin Jones, 'Pulling teeth in eighteenth-century Paris,' Past and Present, Feb. 2000 166: $100-45$.

${ }^{39}$ Dejean, pseud., (Antoine Hornot), Traité des odeurs, Paris, 1764, pp. 226-7; Bourdet, op. cit., note 37 above, pp. 28-9.

${ }^{40}$ Le Bègue de Presle, op. cit., note 34 above, p. 340; Vigarello, op. cit., note 12 above, p. 146. For a contemporary view, see Pierre Roussel, Système physique et moral de la femme, ou tableau philosophique de la constitution, Paris, chez Vincent, 1775 , p. 88.

41 “... répercutent vers les parties internes la matiere dangereuse", Roussel, op. cit., note 40 above, p. 128.
}

\footnotetext{
42 “. . . la substance spongieuse du poulmon", Gendron, op. cit., note 35 above, p. 20.

${ }^{43}$ Madame de Merteuil lost an eye and was said to have "her soul ... in her face", P A F Choderlos de Laclos, Dangerous acquaintances, transl. Richard Aldington, London, Routledge, 1924, p. 428. 44 “. . . si vous osez vous gratter, vous resterez si laide que personne ne vous aimera plus". Casanova went on to say, "One can defy all the physicians of the universe to find a more powerful impediment to itching than that of a young girl who knows she used to be beautiful, and who sees herself exposed to becoming ugly by the fault of her scratching"; "On peut défier tous les physiciens de l'univers de trouver un frein plus puissant contre la démangeaison d'une fille qui sait avoir été belle, et qui se voit exposée à devenir laide par sa faute si elle se gratte". Giacomo Casanova, Mémoires de Jacques Casanova de Seingalt, Paris, Paulin, 1843,
} p. 52. 
of inoculation and then vaccination. ${ }^{45}$ Mercier entreated fathers of the lower classes to take advantage of this new discovery, asking "why does the Parisian obstinately wish to see the nose and cheeks of his daughters eaten and scarred ... when they could conserve the polish ... which would make them the most charming creatures of Europe"? ${ }^{46}$ The popularization of inoculation gave women one less reason to feel insecure about their looks, rendering medical arguments against cosmetics even more persuasive.

Ultimately, doctors felt that through the use of science they could provide better solutions for women than the application of make-up. It was hoped that women would learn

by the experience of others that the best make-up cannot repair the injuries of time, nor re-establish lost beauty, that on the contrary cosmetics are only capable of ruining the skin, wrinkling it, altering it and fading natural colours. ${ }^{47}$

Young women were those in the most danger of becoming addicted to dangerous fashions. Early prevention of this allowed "their complexions to conserve their freshness longer". ${ }^{48}$ Cosmetics were the ultimate destroyers of young girls' bodies, not sin and debauchery.

Many doctors felt, however, that their admonitions would have little effect as "health, beauty and the desire to live can do nothing against a servile, absurd, expensive, dirty and unbecoming imitation" of fashion. ${ }^{49}$ Tissot, after laying out the many dangers of the use of cosmetics in his treatises, concluded that "unfortunately these examples are not frightening enough" as most women would simply ignore his advice. ${ }^{50}$ Doctors felt overwhelmed by

\footnotetext{
${ }^{45}$ Inoculation for smallpox was available by the second half of the eighteenth century. Fears that it would trigger the disease, however, meant that it was not popular. In 1761 the Avant Coureur encouraged the public to be inoculated, since the mortality rate was low. One year later, d'Alembert was quoted in the Mercure de France advising inoculation, but it was not until the end of the century that it became commonplace. In France, the doctor Théodore Tronchin introduced and popularized inoculation in 1756. Avant Coureur, 20 April 1761, p. 244; Mercure de France, Jan. 1762, pp. 108-116; Henry Tronchin, Un médecin du XVIII siècle, Théodore Tronchin, Paris, Plon, 1906, pp. 105, 116-117. For more on the problem of smallpox, see J P Peter, 'Les médecins français face au problème de l'inoculation variolique et de sa diffusion, 1750-1790,' La médicalisation en France du XVIIIième au début du XXième siècle, Colloque de l'Université de Rennes-II, in Annales de Bretagne et des Pays de l'Ouest, 1979, 86: pp. 251-64. For a contemporary view of the disease, see Pajon de Moncets, Dissertation sur la petite vérole ... dans laquelle on donne ... les moyens de prévenir les dommages qu' elle fait à la beauté, Paris, chez Antoine Boudet, 1758.

46 "Pourquoi le Parisien s'obstine-t-il à voir le nez et les joues de ses filles rongés et cicatrisés ...
}

lorsqu'elles pourraient conserver ce poli qui ... en ferait les plus charmantes créatures de l'Europe", Louis-Sébastien Mercier, Tableau de Paris, vol. 4, ch. 342, in Paris le jour, Paris la nuit, Paris, Robert Lafont, 1990, p. 171.

47 ،... par l'expérience des autres que le meilleur fard ne peut point réparer les injures du temps, ni rétablir une beauté qui s'est évanouie, qu'au contraire ils ne sont propres qu'à gâter la peau, la rider, l'altérer, et faire disparoître les couleurs naturelles", Jaubert, op. cit., note 30 above, vol. 4, p. 545 .

48 “... leur teint en conservera plus longtemps sa fraîcheur”, P Virard, Essai sur la santé des filles nubiles, London, Monory, 1776, p. 32.

49 “... la santé, la beauté, le désir de vivre ne peuvent rien contre une imitation servile, absurde, dispendieuse, sale et qui enlaidit", Dr Noël Retz, Nouvelles ou annales de l'art de guérir, 7 vols, Paris, 1785-1791, vol. 5, p. 532.

50 “... malheureusement tous ces examples n'effrayent point assez". Tissot, op. cit., note 13 above p. 265. On Tissot and make-up, see Solange Simon-Mazoyer, 'Le conflit entre les excès de la mode et de la santé au XVIIIe siècle, l' "habillage" du visage,' in Vincent Barras and Micheline LouisCourvoisier (eds), La médecine des lumières: tout autour de Tissot, Geneva, Georg, 2001, pp. 41-53. 


\section{Morag Martin}

the power of charlatans to sway women with promises of false beauty. Some of their own colleagues were issuing permissions for questionable cosmetics and were even selling their own inventions to the avid consumer public. ${ }^{51}$

Yet, the popularization of medical opinions in recipe manuals and journals indicates that the dangers of cosmetics were becoming widely accepted. The fears of harmful medicines meant an increase in the policing of recipe books written by perfumers and other artisans. In 1761, Le parfumeur royal could only be published after all recipes in which oxidized lead, carbonated lead, corrosive mercury chloride, alum or nitrate were omitted by order of Jean-Etienne Guettard, the naturalist and geologist, who had been asked to inspect its content by the censors. ${ }^{52}$ Though government censorship may not have caught all chemicals, writers made sure to announce their own purging of noxious ingredients. A distiller wrote in his introduction: "I would reproach myself even more, if, among recipes for the maintenance of beauty, I had inserted a few whose nature was to alter health, this blessing a thousand times more precious". ${ }^{3}$ Two popular early-nineteenth-century perfumers made good use of Le Camus's earlier recipes but criticized his lack of real medical knowledge, calling on modern chemistry to correct his mistakes. ${ }^{54}$

The strength of medical arguments influenced not only perfumers' manuals, but encyclopaedias and newspapers as well. The many articles on cosmetics in Denis Diderot's Encyclopédie commented openly on their dangers. The article on blanc warned that those containing lead, vinegar and bismuth, "which make in truth the most beautiful white paints in the world", were also, "due to their salivary, poisonous, arsenic, indelible properties", the most harmful. 55 Abbé Jaubert's Dictionnaire raisonné, which for the most part provided definitions and descriptions of trades without comment, was harshly critical of the ingredients employed by perfumers. The dictionary concluded, "it is thus dangerous to use all cosmetics which block the skin, dry it and wear it down imperceptibly". 56 The popular press also took on the task of warning the public about the dangers of cosmetics. In 1777, La feuille sans titre published a doctor's findings on cosmetics. The article emphasized that

\footnotetext{
${ }^{51}$ Sellers of cosmetics who wished to advertise had to get an official permission from the Société Royale de Médecine. Sixty-two per cent of cosmetics were given a tacit approval, and rejections were more often for lack of originality than the presence of a dangerous ingredient. For a full analysis of the patent system, see Morag Martin, 'Entrepreneur or charlatan? The commerce of cosmetics, patents and the medical profession in France 1750-1830', in Liliane Hilaire Perez (ed.), Pratiques historiques de l'innovation $X V e-X X e$ siècle, Paris, Centre d'histoire des techniques, 2003, pp. 103-15.

${ }^{52}$ Anon., Le parfumeur royal ou traité des parfums, Paris, 1761, p. 143.

53 “Je m'en ferais un bien plus grand [reproche], si, parmi les recettes propres a entretenir la beauté, j'en avais inséré quelques unes qui fussent de nature a altérer la santé, ce bien mille fois plus précieux". Dejean, op. cit., note 39 above, pp. v-vj.
}

\footnotetext{
${ }^{54}$ Auguste Caron, Toilette des dames ou encyclopédie de la beauté, Paris, A G Debray, 1806, pp. 28-30; Fargeon, op. cit., note 18 above, p. 2.

55 “... qui font en vérité les plus beaux blancs du monde, mais qui par leurs parties salives, vénéneuses, arsénicales, indélébiles, altèrent et gâtent le teint sans remède", article by Jaucourt, in Denis Diderot and Jean Lerond d'Alembert (eds), Encyclopédie ou dictionnaire raisonné des sciences, des arts et des métiers, 17 vols, Paris, 1765, vol. 4, pp. 291-2. The Encyclopédie also provided recipes for cosmetics. See Terry Smiley Dock, Women in the Encyclopédie: a compendium, Potomac, MD, Studia Humanitatis, 1983, pp. 66-7.

56 ، ... il est donc dangereux d'user de tous ces fards cosmétiques qui plombent la peau, la desséchent et la minent insensiblement", Jaubert, op. cit., note 30 above, vol. 4, pp. 362-3, 271
} 
women could not take enough precautions to assure the safety of the products they bought and wore. ${ }^{57}$

Much of this advice was specifically aimed at women, who were thought to need more education in the sciences that pertained to their lives. A letter written to the Journal des Dames hoped that the writings of medical doctors "could enter into the toilettes of women who would then see the multitude of accidents produced by make-up". ${ }^{58}$ Literate middleclass women could acquire medical information from these books or a diversity of other sources without direct access to a physician. Since readers shared books and newspapers, these ideas were likely to be quickly disseminated through conversation as well. The overwhelming medical consensus against the application of cosmetics for medical reasons would have been hard to avoid and even harder to refute. Once women were warned of possible dangers, they could arm themselves with further knowledge, no longer trusting the promises of their perfumer or the corner charlatan, turning instead to a respectable physician. There was no need for these professionals to stress the links between immoral behaviour and artifice, since the cosmetics themselves provided a much more effective punishment for vanity.

By specifying the need for a masculine, medical presence at a woman's daily toilette, doctors also eliminated its association with sexual and theatrical intrigue. In the literature of the Old Regime, the ritual of beautification was a complex and public display of feminine attractions to a group of fawning men. Under the supervision of a doctor, the cabinet de toilette was to be rehabilitated into a functional and practical space rather than a site for pleasure and passion. Doctors made the production of home remedies based on their recipes or the buying of goods based on their advice essential to a young girl's upbringing. By imposing on their readers a teacher, they put more emphasis on masculine learning and knowledge than on female ingenuity. The tradition of oral recipes passed down from mother to daughter, was to be replaced by published recipes or store-bought concoctions properly vetted. The male medical knowledge needed for the transmission of beauty distanced women from their own beautification processes, inserting doctors in their midst. Medical advice allowed male professionals to enter private spaces not as lovers or servants, but as all-knowing supervisors who firmly closed the door of the now domesticated cabinet de toilette behind them.

\section{Scientific Vanity: The Educated Woman at Her Cabinet de Toilette}

Medical and professional experts aimed to shape the creation and purchase of cosmetics. Yet, the genre of beauty manuals itself gave the assumed audience of female readers the final say in the content of these works. Doctors could rail against cosmetics, but by publishing advice they would ultimately have to provide solutions to beauty problems.

\footnotetext{
${ }^{57}$ Feuille sans titre, 10 Feb. 1777 , p. 38.

58 “.... puissent parvenir jusqu'à la toilette des Dames; elles y verraient une foule d'accidents
}

produits par le fard"; 'Lettre sur les dangers du fard', Journal des Dames, Aug. 1761, pp. 188-90, on p. 189. 


\section{Morag Martin}

The dual purposes of manuals coexisted: doctors hoped to limit and control the use of cosmetics, while readers expected the inclusion of advice for the enhancement of beauty. Authors who published their advice were distinctly aware of the importance of public opinion, specifically that of their readership. Dr Jean Goulin bent to the demands of his female patients. These women, confused by the multitude of books on cosmetics, asked him to "extract from these different authors what you judge best suits us". Though he found such a task belittling, he assured his readers that he gave it "all [his] attention". 59 Despite their dislike of such works, doctors realized that popular books of advice helped to establish their names outside their clientele and discredit the work of those they saw as charlatans.

The doctors' awareness of their audience's needs led them to omit discussions of moral behaviour. Instead of linking cosmetics directly with corruption and sin, as many previous critics had done, they instructed women in the conduct most suitable for enhancing their looks. In this they were influenced by moral physiologists, who argued that behaviour and emotions had physical and often dangerous effects on the body. ${ }^{60}$ For instance, they pointed out that too much dancing, drinking and sun led to unhealthy skin. Though such comments might be read as a moral judgment of women's lifestyles, other less questionable emotional states and physical activities were also blamed for causing bad skin: sadness, fear, remorse, over-work, lack of exercise and bad digestion. ${ }^{61}$ This list makes specific assumptions about women's lifestyles and physical capabilities: women had softer bodies and more sensitive nerves. Yet, similar lists can be found in medical advice manuals aimed at men. Ultimately, doctors viewed excess of any kind as potentially dangerous for healthy living, and by stressing the threat to women's beauty they hoped to induce more moderate habits. Though Wilson argues that the medical regulation of women's bodies was played out in moral terms, advice manuals for the most part stressed physical rather than spiritual repercussions. ${ }^{62}$

The tone of advice literature was practical and straightforward, discrediting those who tried to use morality as a means for regulating fashion and beauty. For example, Marie de Saint-Ursin argued that a pure girl's position in society could not be harmed by her application of make-up, as long as this practice did not endanger her health or inherent beauty. He stated plainly that "honest young women will stay thus despite the resources which we present to them". He blamed men who seduced girls into lives of sin, and not cosmetics, for any immoralities present in French society. Criticism of cosmetics for medical reasons was one thing, but Marie de Saint-Ursin was not willing to assume a correlation between beauty and sin. His goal was to educate women in

59 “... extraire de ces différens auteurs ce que vous jugerez nous convenir le mieux", "toute mon attention", Jean Goulin, Médecin des dames, ou l'art de les conserver en santé, Paris, 1771, p. ix. Some of the works listed by Goulin are Marie Meurdrac, La chymie charitable et facile en faveur des dames, 1666; Philbert Guybert, Le médecin charitable, 1627; Le Camus, Abdeker; Dejean, Traité des odeurs.

\footnotetext{
${ }^{60}$ Ludmilla Jordanova, Sexual visions: images of gender in science and medicine between the eighteenth and twentieth centuries, Madison, University of Wisconsin Press, 1989, pp. 27-9.

${ }^{61}$ Le Camus, op. cit., note 36 above, vol. 1, pp. 172-4; Marie de Saint-Ursin, op. cit., note 27 above, p. 302; Dejean, op. cit., note 39 above, p. 167.

${ }^{62}$ Wilson, op. cit., note 11 above, p. 13.
} 
the utility and safety of beauty products, while encouraging exercise, baths and proper daily hygiene. ${ }^{63}$

Advice manuals and recipe books were by definition advocates of cosmetics, though the range and utility of products listed differed. Marie de Saint-Ursin only condemned "artificial compositions ... because of the harm they do to women and not because of the harm that they could do to their happy dupes". ${ }^{64}$ Forms of make-up that were not artificial (and thus chemical) were acceptable means of attracting the stares of men or jealous rivals. Not all other doctors advocated layers of paint, yet most found ways to advise women to keep up the glow of youth and reduce the onslaught of time. Despite his reluctance to include cosmetics, Goulin listed a large number of traditional recipes at the end of his Médecin des dames, even a face paint made with silver litharge (the residue of lead oxide) and white vinegar, two very questionable ingredients. ${ }^{65}$ Gendron, one of the harshest critics of cosmetics, proposed replacing chemical face paints with alcohol-based astringents meant to whiten the skin. ${ }^{66}$

Instead of lecturing women about their moral duties, writers of advice manuals stated that vanity and pride were necessary social traits rather than sinful failings. These doctors felt that "it would be missing out on what one deserves to refuse oneself simple and well-known ways of gaining the satisfaction of pleasing oneself and others". ${ }^{67}$ Thus, basic knowledge of beauty should not be suppressed if it allowed society to be more pleasant, and with it healthier and happier. It was natural for women to want to please both themselves and the men around them. Pride in one's looks allowed for visual and sensory pleasures that benefited men and women alike, and was essential to a happy marriage. ${ }^{68}$ Men were warned that young girls who at fifteen did not seek to please would turn into very disagreeable wives at twenty-five. ${ }^{69}$ The key to happiness was personal satisfaction and a healthy dose of vanity. The ambition to primp and please was "the soul of society and we can state that both sexes obey equally this law of nature". ${ }^{70}$ The soul, which had been labelled as tainted due to the presence of make-up by numerous critics of cosmetics, could be saved through a simpler version of pleasurable vanity.

Science validated the notion that beauty and vanity were part of the laws of nature, but only for women. Pierre Roussel's influential Système physique et moral de la femme

\footnotetext{
63 “... fille honnête restera telle malgré les ressources que nous lui présentons", Marie de Saint-Ursin, op. cit., note 27 above, pp. 276-7, 278.

64 ،... compositions artificielles ... par le tort qu'elles font aux femmes et non par celui qu'elles pouraient faire à leurs heureuses dupes", Marie de Saint-Ursin, op. cit., note 27 above, pp. 276-7.

${ }^{65}$ Goulin, op. cit., note 59 above, pp. $429-30$.

${ }^{66}$ Gendron, op. cit., note 35 above, p. 26.

67 “Ce serait manquer à ce que l'on se doit, que de se refuser des choses simples et connues, pour procurer la satisfaction de se plaire a soi-même
}

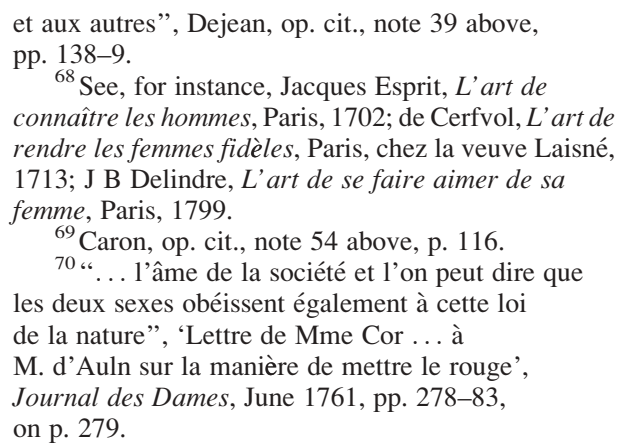

et aux autres", Dejean, op. cit., note 39 above,

${ }^{68}$ See, for instance, Jacques Esprit, L'art de connaître les hommes, Paris, 1702; de Cerfvol, L'art de rendre les femmes fidèles, Paris, chez la veuve Laisné, 1713; J B Delindre, L'art de se faire aimer de sa mme, Paris, 1799

${ }^{69}$ Caron, op. cit., note 54 above, p. 116. 70 ،... l'âme de la société et l'on peut dire que de la nature", 'Lettre de Mme Cor ... à M. d'Auln sur la manière de mettre le rouge', on p. 279. 


\section{Morag Martin}

defined a vision of women's health that was firmly linked to their physical traits. ${ }^{71}$ Because women were weak they needed male protection. The means for achieving this end was their beauty, since men would be biologically attracted to beautiful women whose looks represented their health and fertility. The biological explanation for beauty focused on women's roles as wives and, more importantly, as mothers. Once the task of childbearing was finished, beauty and its alter-ego vanity were no longer necessary and most often faded away. ${ }^{72}$ The scientific validation of vanity in pre-menopausal women allowed doctors to advocate the continued use of beauty aids. Letting the face deteriorate naturally was not a practical means of ensuring the love of a husband. It was the wife's job to keep her husband desirous of her, thus increasing her need for valid medical counsel. A very humorous version of such counsel can be found in the Dentiste des dames, which argued that if a husband left his wife it was her fault for not having taken better care of her teeth. ${ }^{73}$

The acceptance of vanity as an ultimately feminine and necessary trait was part of a traditional emphasis on female reproductive functions that can be dated back to the Renaissance. Yet, it also demarcated a new role for beauty as a social necessity for respectable families. Women's beauty practices were essential to what Thorstein Veblen calls "conspicuous consumption", in which women stood in for their husband's or father's ability to afford leisure. ${ }^{74}$ When it came to the use of make-up, however, this was not an extravagant display of luxury, but a subtle form of tasteful and literally inconspicuous consumption. Women who wore rouge and powder by the end of the century hoped to do so undetected, highlighting their natural beauty and health, reinforcing the biological justifications for the toilette. Unlike the artifice of the early eighteenth-century, this use of invisible beauty aides was meant to underline the individual's taste and worth as part of the bourgeois family unit. The use of private, and thus hidden, make-up was necessary for public presentation and yet was not to be openly discussed or noticed.

In this newly privatized cabinet de toilette, the doctor was to be not only the trusted adviser but also the confidant who would protect the secret uses of artifice under a different name. In 1804, Marie de Saint-Ursin tried to deny this role of confidant, wanting women to be more honest with themselves and their entourage about their use of make-up. Though these women had given up wearing the thick layers of paint of the Old Regime aristocracy, they still adopted light rouge and white powder, justified because it was worn "without artifice, in truth, and only to seem less frighteningly ugly". He goaded these women by proclaiming them "vain and lying", and asked sarcastically "is this

\footnotetext{
${ }^{71}$ Roussel's work was re-edited five times between 1775 and 1809 and it influenced writers such as Jacques-Louis Moreau de la Sarthe and Julien-Joseph Virey. Yvonne Knibiehler and Catherine Fouquet, La femme et les médecins, Paris, Hachette, 1983, pp. 86-7.

${ }^{72}$ Knibiehler and Fouquet, op. cit., note 71 above, p. 91. Roussel was one of the first doctors to stress that a woman's organism was different in its form and
}

function from a man's. Lieselotte Steinbrügge,

The moral sex: woman's nature in the French

Enlightenment, trans. Pamela E Selwyn, New York,

Oxford University Press, 1995, p. 43.

${ }^{73}$ Joseph Lemaire, Le dentiste des dames, Paris, Foucault, 1812, p. 125.

${ }^{74}$ Thorstein Veblen, The theory of the leisure class, 1st ed. 1899, New Brunswick, Transaction publishers, 1992, p. 68. 
carmine not make-up"? ${ }^{75}$ What Marie de Saint-Ursin wanted was an open dialogue about the social importance of vanity and artifice, something that was unlikely to happen in the context of naturalized, transparent beauty. Though he would not get public confessions of rouge wearing by the new bourgeois élite, his recipes allowed them, safely and without guilt, to continue their private ablutions. The doctor and his findings were being used to justify a continued use of paint, legitimating the practice of primping in the name of science.

While respectable women bought medical tracts and made up in private, men were no longer allowed around the toilette table. The transfer of display to the female body left the male body with no exhibitionary role. What J C Flügel labels the "great masculine renunciation", banned men from the practices of primping, leaving them with the passive role of voyeur. ${ }^{76}$ This biological separation of the sexes permeated the tone of medical advice at the end of the eighteenth century. Advice on beauty was aimed at a female audience only. ${ }^{77}$ Yet, doctors worried that this division between the sexes had gone too far. Men told to give up cosmetics might also give up the practices of health and hygiene. Goulin addressed this problem in his medical work aimed at men saying, "many people think that all these little details belong only to women and that it is futile for a man to care about them". He stressed that many of these "little details" of the toilette were also indispensable to men. Yet, in order for men to learn the skills of grooming, they had to turn to his earlier work Médecin des dames. ${ }^{78}$ Authors were acutely conscious of the stigma attached to male coquettes. A treatise on the mouth admonished men to take care of their teeth, even though "men, for fear of seeming ridiculous, do not adopt the cares which are reserved to women". ${ }^{79}$ Men were assumed to have left the cabinet de toilette entirely, leaving to their wives all aspects of beauty, even those seen as essential. $^{80}$

Medical advice advocated an acceptance of feminine vanity based on social and biological necessities, while excusing men from the cabinet de toilette for the same reasons. Distancing themselves from the severe criticisms of the philosophes, doctors gained a tenable middle position in which they could decry cosmetics for medical reasons while at the same time proposing to make women's lives more pleasant through the application of make-up. Rather than simply scare or scold their audience, doctors wooed female readers by offering them real solutions to everyday problems within a domestic setting. Beauty manuals provided rational, scientific arguments for and against beauty products, justified

\footnotetext{
75 “... sans artifice, en vérité, et seulement pour ne pas être effroyables", "vaines et mensongères", "ce carmin n'est pas du fard?" Marie de Saint-Ursin, op. cit., note 27 above, p. 209.

${ }^{76} \mathrm{~J}$ C Flügel, The psychology of clothes, London, Hogarth Press, 1930, pp. 110-13.

${ }^{77}$ Many of these works were dedicated to the fair sex, rather than, as earlier books of recipes, to the royal family.

78 “... . bien des gens croient encore que tous ces petits détails n'appartiennent qu'aux femmes et que c'est une peurilité chez un homme
}

de s'en occuper", Jean Goulin, Médecin des hommes, Paris, Vincent, 1772, pp. 409, 163-4.

79 “. . . les hommes, à peine d'être ridicules, ne prétendent point aux agrémens qui sont reservés aux femmes", Bourdet, op. cit., note 37 above, p. 5.

${ }^{80}$ It is unlikely that men had truly given up on cosmetics. Account books of perfumers indicate a continued male clientele up to the Revolution. What did change was the types of cosmetics men used, with an emphasis on hair potions and face creams rather than make-up. Martin, op. cit., note 3 above, p. 31 . 


\section{Morag Martin}

by social expectations and biological urges. The women who read these books did so to shape their now private practices. The use of cosmetics was still largely defined by fashion, but the specific products applied, their methods and legitimacy lay primarily in the realm of science.

\section{Conclusion}

The growing importance of the medical profession to the feminine toilette and the repercussions of this for the use of cosmetics can be illustrated by one example. In 1778 the Affiches de Provence published a letter from a young woman asking a doctor's advice about the wearing of make-up. Her mother had employed moral and aesthetic arguments against its use, believing that only vain girls trying to deceive men and snatch a husband dyed their hair and powdered their faces. The young woman, hoping for a second opinion, asked the doctor to "make me capable of proving to my mother that this drug does not harm the skin and that my application of it is not incompatible with modesty and virtue". She put herself into his hands as "you are the doctor, I must hide nothing from you". ${ }^{81}$ The doctor's reply was that even though there were neither moral nor aesthetic reasons against wearing make-up, there were medical ones. He warned her that, "it is absolutely impossible for me to prove that make-up will not harm the skin". But, not wishing her to think he was mollifying her mother, he included recipes for cosmetics by a medical colleague that were sure to be safe. ${ }^{82}$ This dialogue indicates the ascendancy of medical discourses in matters of beauty: the young girl trusted medical advice and the doctor based his judgments on scientific reasoning. With neither moral nor aesthetic reasons to deny the use of make-up, this representative of science had to agree, however unwillingly, that some safe cosmetics were socially acceptable.

The Alliance d' hygie et de la beauté, which had attracted such a crowd at the time of its publication in 1818, provides us with a different version of medical supervision. The same journalist who noted the chaos it produced, critiqued the content of the book. Mège's work was compared to Le Camus's still popular Abdeker published in 1753. Unlike the old favourite, the Alliance was found to be a much harsher model for women to follow. Mège insisted that women "throw out of the window all their bottles, all their pretty porcelain jars; he condemns without pity their marvellous washes, admirable creams, miraculous elixirs". 83 The publication of his book may have stirred up a frenzy, but Mège would surely not be women's favourite for long as he did not provide them solutions to their

\footnotetext{
81 “... me mettre en étât de lui prouver que cette drogue ne gâte point la peau, et que l'usage que j'en fais n'es pas incompatible avec la sagesse et la vertu", "vous êtes Médecin; je ne doit rien avoir de caché pour vous", Affiches de Provence, Aix, 8 Nov. 1778 , p. 353.

82 "Il m'est absolument impossible de demontrer que le fard ne gâte point la peau",
}

\author{
Affiches de Provence, Aix, 15 Nov. 1778, \\ pp. $358-9$. \\ 83 “.... il veut que vous jetiez par la fenêtre \\ toutes vos fiolles, tous vos jolies petits pots de \\ porcelaine; il proscrit impitoyablement vos eaux \\ merveilleuses, vos crèmes admirables, vos élixirs \\ miraculeux", Gazette de France, 4 Sept. 1818, \\ 247: 1034-35.
}


beauty problems. Undoubtedly, the next doctor willing to offer solutions rather than admonitions would quickly overshadow Mège's popularity.

The anonymous doctor of the Affiches represented a man of science who was willing to condone the wearing of rouge and powder as long as they were safe. Mège represented a stricter type of doctor who emphasized hygiene and natural beauty over all fantasy and vanity. Medical practitioners could attempt to proscribe the uses of cosmetics, yet as long as their colleagues offered recipes for safe face whiteners and rouge, medical science would continue to support their use. The biological and social arguments in favour of feminine vanity helped give legitimacy to these options, but ultimately, scientific experiments came first. Knowledge about ingredients, and their effects, was a means of controlling the toilette without question. It gave physicians well-defined boundaries (created by them) by which they could justify their presence in a world of feminine frivolity.

Yet, this position of control was neither uncontested nor inflexible. By opening the door for "objective" scientific experiments, doctors allowed many vegetable substances to pass their tests and become acceptable cosmetics in the thriving consumer market for beauty goods. The Société Royale de Médecine, which tested cosmetics sent to them for approval, gave patents to all rouges fabricated with innocuous oil, saffron, lemon and talc. They also trusted the recipes sent to them by manufacturers, thus ignoring that the key ingredient, caustic potash, had been left out. ${ }^{84}$ In turn, this permission allowed sellers to label their product as medically approved "vegetable rouge", providing for a huge increase in sales. These sellers were also well aware of the power of medical language, proudly printing the texts of their patents in their advertisements. ${ }^{85}$

Though it is harder to find evidence for consumer attitudes, women who bought cosmetics also had access to medical language and justifications to shape their practices. The information provided by scientific dictionaries, medical advice manuals, and even advertisements, allowed women to make increasingly more sophisticated judgments when it came to the products they used on their faces and bodies. In the midst of public disapproval, this specialist knowledge gave female users a means by which to reclaim beauty practices for themselves. The medical practitioner's advice manual in the cabinet de toilette was an ally rather than an enemy, a qualitative addition to books of endless and undifferentiated recipes by perfumers. He set the limits on products, while leaving the practice up to the user's discretion and personal definitions of attractiveness, allowing for flexibility in the use of make-up. Even though medical manuals were overshadowed by the second half of the nineteenth century by brand name cosmetics and recipe books written by

\footnotetext{
${ }^{84}$ In 1781, the widow Quesnel points out to the doctors that the only reason they rejected her rouge is that she was honest about this ingredient. All other rouge recipes leave out the potash. Académie nationale de médecine, ASRM box 103 , d 71 . For more on how doctors judged cosmetic products, see Martin, op. cit., note 51 above.

${ }^{85}$ For instance, see the advertisement for Collin's rouge: Annonces, affiches
}

et avis divers, 27 May 1780, p. 1213. Balzac was well aware of this practice, having his eponymous César Birotteau visit the chemist Vauquelin to gain a scientific approval for a worthless hair potion. The novel was inspired by Balzac's reading of Le Camus' Abdeker, from which he appropriated names of products. Martin, op. cit., note 51 above, p. 114. 


\section{Morag Martin}

actresses and noble women, medical language continued to be used to justify ingredients and recipes. ${ }^{86}$ And the legacy of medical beauty can be found today in the prominent pseudo-scientific names of popular cosmetics, the use of "laboratoire" and "docteur" by cosmetics companies, and the pharmaceutical monopoly of prominent cosmetic brands.

${ }^{86}$ Late-nineteenth-century concerns with health and hygiene led to the publication of beauty books by hygienists that aimed to lure women with promises of solutions. Mary Lynn
Stewart, For health and beauty: physical culture for Frenchwomen 1880s-1930s, Baltimore, Johns Hopkins University Press, 2001, pp. 37, 197. 